\title{
MACCABE V. WESTLOCK: \\ The Use of Male Earnings Data to Forecast \\ Female Earning Capacity
}

\section{Christopher J. BruCE, Ph.D.}

In a line of decisions which recently culminated in the Alberta case of MacCabe v. Westlock Roman Catholic Separate School District,' the courts have used average earnings statistics for males as the basis for estimating the future earnings of young, female plaintiffs. Two arguments have been offered for adopting this approach.

The first is that forecasts of future earnings patterns find that female earnings will resemble the historical patterns associated with males more closely than the historical patterns associated with females. This argument, which I will call the statistical prediction approach, has two variants. In one, it is argued that the male/female wage gap will decrease sufficiently rapidly that, within two decades, the incomes women earn over the course of their careers will be similar to those experienced by men today. Hence, when predicting the earnings of a plaintiff who is a child today, it is best to rely on male earnings patterns. In the other, it is argued that career paths within narrowly defined occupations may not differ significantly between males and females. Hence, if the plaintiff is old enough that it is possible to specify the precise occupation she would have entered, the prediction of her future earnings will be similar to those of a comparable male. That is, a prediction based on statistical evidence would lead one to use data that resembled those historically associated with male earnings.

The second argument is that, even if the male/female wage gap does not close, it would be discriminatory to award a lower level of damages to a female plaintiff than to a male plaintiff. Mitchell McInnes $^{2}$ has referred to this argument as the gendered earnings proposal.

In this comment, I consider both of these arguments. I begin, in Section I, by reviewing the empirical evidence concerning the sources of the wage gap between men and women. In Section II, I identify the implications of the empirical evidence for the determination of loss of earnings in three classes of cases. Finally, in Section III, I contrast the implications discussed in Section II with the decisions in fourteen Canadian cases.

- Professor of Economics, University of Calgary. President of Economica Ltd., a consulting firm that specializes in the calculation of damages in personal injury and fatal accident cases. In his latter capacity, he appeared as an expert economist on behalf of the plaintiff in MacCabe v. Westlock. The author would like to thank Derek Aldridge and Scott Beesley for their helpful comments. (1998), 226 A.R. I (Alta. Q.B.), online: QL (AJ) [hereinafter MacCabe].

M. Mclnnes, "The Gendered Earnings Proposal in Tort Law" (1998) 77 Can. Bar Rev. 152. Sec also E. Gibson, "The Gendered Wage Dilemma in Personal Injury Damages" in K. CooperStephenson \& E. Gibson, eds., Tort Theory (Toronto: Captus, 1993) 185; and J. Cassels, "Damages for Lost Earnings Capacity: Women and Children Last!" (1992) 71 Can. Bar Rev. 445. 


\section{EMPIRICAL EVIDENCE}

In 1975, the average annual income of individuals who were working full-time, fullyear was \$8,231 among women and \$13,674 among men - resulting in a female/male earnings ratio of 60.2 percent. By 1995 , women's earnings had risen to $\$ 29,700$ and men's to $\$ 40,610$ - a ratio of 73.13 percent. $^{3}$ In a period of only two decades, the female "deficit" had fallen from 40 percent to less than 30 percent. The purpose of this section is to consider whether this trend can be expected to continue into the future and whether any remaining wage gap will be due to observable differences between men and women or whether it will be due to discrimination.

The section begins by identifying a number of sources of earnings differentials between males and females that could arise for reasons other than discrimination. Two sources of discrimination will be considered - systemic discrimination and labour market discrimination. The former refers to discrimination that is endemic within our educational system, entertainment industry, and cultural institutions. This type of discrimination may influence the tastes and preferences of men and women, leading women to make different choices concerning participation in the labour market than are made by men. The second form of discrimination is that which is suffered within the labour market, at the hands of employers, fellow employees and customers.

\section{A. Differences Between MEN AND WOMEN}

Men's earnings could differ from women's even in the absence of labour market discrimination. Women may, for example, enter different occupations from men, have less or more work experience than men, or have, on average, different work skills than men. Some of the most commonly cited sources of such differences will be considered here. For the purposes of this section, it will be assumed that observed differences do not arise from systemic discrimination. That possibility will be discussed in a subsequent section.

Labour force participation: In any year, the probability that a woman will be in the labour force - that is, working (employed) or looking for work (unemployed) - is lower than the comparable probability for a man. Hence, over her lifetime, she will earn less income than would a comparable male. Table 1 indicates that although this difference has narrowed dramatically in the last four decades, a gap of slightly more than 10 percentage points persists. Table 2 confirms that much of this gap results because a significant percentage of women leave the labour force to care for young children. 


\section{TABLE 1}

labour-force participation Rates by age and Sex, CANADA, 1931-1996

MALES

\begin{tabular}{ccccccc}
\hline & $15-24^{\mathrm{b}}$ & $25-34$ & $35-44$ & $45-54$ & $55-64$ & $65+$ \\
\hline $1931^{\circ}$ & 80.6 & 97.7 & - & 95.9 & - & 55.7 \\
$1941^{\mathrm{h}}$ & 76.2 & 98.4 & 98.9 & 97.4 & 91.1 & 48.5 \\
1951 & 75.6 & 96.4 & 96.7 & 94.5 & 85.7 & 38.6 \\
1961 & 61.8 & 94.1 & 94.3 & 91.9 & 81.9 & 28.4 \\
1971 & 65.3 & 92.6 & 92.8 & 90.3 & 80.1 & 23.6 \\
1981 & 73.1 & 95.2 & 95.1 & 92.0 & 76.9 & 16.3 \\
1986 & 72.4 & 94.3 & 94.6 & 91.2 & 70.6 & 13.7 \\
1991 & 68.9 & 94.0 & 94.5 & 91.5 & 66.5 & 14.4 \\
1996 & 65.8 & 92.2 & 91.8 & 89.3 & 58.7 & 10.6
\end{tabular}

FEMALES

\begin{tabular}{lcccccc}
\hline & $15-24^{\mathrm{b}}$ & $25-34$ & $35-44$ & $45-54$ & $55-64$ & $65+$ \\
\hline $1931^{\circ}$ & 36.6 & 21.7 & - & 12.0 & - & 6.2 \\
$1941^{\mathrm{h}}$ & 41.4 & 25.0 & 16.3 & 13.1 & 11.0 & 5.6 \\
$1951^{\circ}$ & 42.4 & 24.2 & 21.8 & 20.4 & 14.5 & 5.1 \\
$1961^{\circ}$ & 41.2 & 29.6 & 31.1 & 33.4 & 24.4 & 6.7 \\
1971 & 49.3 & 44.5 & 43.9 & 44.4 & 34.4 & 8.3 \\
$1981^{\circ}$ & 64.8 & 66.0 & 64.4 & 55.9 & 35.5 & 5.4 \\
1986 & 66.8 & 73.6 & 72.1 & 62.4 & 35.9 & 4.2 \\
1991 & 64.9 & 78.5 & 79.6 & 71.9 & 39.2 & 5.6 \\
1996 & 61.4 & 77.3 & 78.5 & 71.8 & 37.3 & 3.6
\end{tabular}

" In 1931, the first age group represents 16-24 year olds. The third figure in the 1931 row represents the participation rate for workers 35-64. The participation rate numerator was taken to be the labour force. The denominator was calculated by taking the population less the number of inmates.

h From 1941 to 1971 , the youngest age group was $14-24$

Sources: Census of Canada, various years; and Statistics Canada, The Labour Force (August 1991 and June 1996). The 1991 and 1996 figures are for May to maintain comparability with the Census figures which relate to May and June. 
TABLE 2

Labour Force Participation Rates for WOMEN By AGe of Youngest Child (Husband Employed), 1990-1996 (\%)

\begin{tabular}{ccccc} 
Year & $\begin{array}{r}\text { Youngest Child } \\
\text { Less than Age 3 }\end{array}$ & $\begin{array}{c}\text { Youngest Child } \\
\text { Age 3-5 }\end{array}$ & $\begin{array}{c}\text { Youngest Child } \\
\text { Age 6-15 }\end{array}$ & $\begin{array}{c}\text { Youngest Child } \\
\text { Over Age 16 }\end{array}$ \\
\hline 1990 & 63.1 & 68.2 & 78.1 & 73.4 \\
1991 & 65.6 & 71.0 & 78.4 & 74.2 \\
1992 & 65.3 & 71.1 & 78.5 & 74.0 \\
1993 & 66.6 & 71.0 & 79.2 & 75.4 \\
1994 & 68.0 & 70.8 & 79.0 & 74.9 \\
1995 & 67.4 & 72.5 & 79.8 & 76.0 \\
1996 & 68.5 & 72.1 & 79.8 & 76.0 \\
Avg. 1990-1996: & 66.4 & 71.0 & 79.0 & 74.8
\end{tabular}

Source: Statistics Canada, The Labour Force, catalogue \#71-001, (Annual Averages), Table 8.

Hours of work: Similarly, as Table 3 indicates, a large percentage of women whose children are less than 16 years old work part-time. These women's earnings will be lower than those of comparable men, even though they are counted as part of the labour force. That is, even if labour force participation rates were to equalize between men and women, women would still earn less, on average, because they are more likely to work part-time.

\section{TABLE 3}

Percentage of Employed Women Working Part-Time BY AGE OF YOUNGEST CHILd (HUSBAND EMPLOYED), 1994-1996

\begin{tabular}{ccccc} 
Year & $\begin{array}{c}\text { Youngest Child } \\
\text { Less than Age 3 }\end{array}$ & $\begin{array}{c}\text { Youngest Child } \\
\text { Age 3-5 }\end{array}$ & $\begin{array}{c}\text { Youngest Child } \\
\text { Age 6-15 }\end{array}$ & $\begin{array}{c}\text { Youngest Child } \\
\text { Over Age 16 }\end{array}$ \\
\hline \multirow{2}{*}{1994} & 27.9 & 30.5 & 27.1 & 18.9 \\
1995 & 26.7 & 28.7 & 24.2 & 17.5 \\
1996 & 29.8 & 31.8 & 27.5 & 21.4 \\
Avg. 1994-1996: & 28.1 & 30.3 & 26.3 & 19.3
\end{tabular}

Source: Statistics Canada, The Labour Force, catalogue \#71-001, (Annual Averages), Table 8.

Recent evidence suggests that women's average weekly hours worked remained virtually constant, as a percentage of men's average weekly hours, over the last two 
decades. ${ }^{4}$ Whereas that ratio was 80 percent in 1971 , it had risen to only 82 percent by 1991. The two most important determinants of this ratio appear to have been education and the presence of young children. Women worked more hours per week, relative to men, as their level of education increased and as the ages of their children increased. $^{\text {s }}$

Experience: A significant amount of training is received on the job. Thus, if women obtain less work experience than men, on average, or choose occupations which offer less training than do the occupations chosen by men, women will be less productive and, therefore, will receive lower incomes than men. What little evidence is available suggests that this may be an important source of wage differences between the sexes. First, as was seen in Table 1, women have lower labour force participation rates than do men. Thus, at any age, women will have fewer years of work experience than will men. Women's lower participation rates mean that they will earn lower lifetime earnings than men both because they work fewer years and because they will accumulate fewer years of work experience. ${ }^{6}$ Second, not only do women have fewer years of work experience in total, it appears that they also have fewer years experience with their current employer. For example, Statistics Canada reports that 39.1 percent of women working full-time in 1988 had worked for their current employer for more than five years, whereas 46.5 percent of men had done so; and that women, on average, had worked 27 percent fewer years with their current employer than had men (5.25 years versus 7.23$)^{?}$

Absenteeism: Because women bear disproportionate responsibility for child care, they are also more likely than their husbands to be absent from work - to care for sick children. Akyeampong ${ }^{8}$ reports that, in Canadian families with children, women averaged 7.3 days per year of "temporary absences from work" due to illness or personal reasons whereas men with children were temporarily absent for only 1.0 day. In families without children, women missed only 2.3 days per year and men 0.8 day.

Occupational choice: It has long been recognized that women are disproportionately represented in low-wage occupations. For example, at the time of the 1971 Census there were 6.75 times as many men as women in the twenty highest paid occupations in Canada. Although this ratio had fallen to 3.83 by the time of the 1981 Census, the ratio of women to men in the twenty lowest paid occupations rose during the same period

Statistics Canada, Women and the Canadian Labour Market: Transition Towards the Future by M. Gunderson (Scarborough: Thomson, 1998) at 78.

Ibid. at 75.

" Of course, as women's labour force participation rates rise, differences in years of work experience can be expected to decrease.

7. At the time of the 1981 Census, Canadian women had accumulated an average of 6.1 years of work whereas men had accumulated an average of 12.5 years; and only 16 percent of women had worked 20 years with the same employer whereas 37 percent of men had done so. (Economic Council of Canada, The Changing Economic Status of Women by J.A. Boulet \& L. Lavallec (Ottawa: Minister of Supply and Services Canada, 1984) at 9).

* E.B. Akyeampong, "Absenteeism at Work" (1992) 25 Canadian Social Trends 26. 
from 1.07 to $1.39 .^{9}$ Similarly, as Table 4 indicates, in 1991 the occupations with the highest percentages of female employees tended to be those with the lowest average incomes. For example, three of the four lowest paid occupations - sales, clerical, and service - were also three of the five occupations with the highest percentages of female employees. Furthermore, 58.0 percent of female employees worked in these three occupations, whereas only 27.3 percent of men worked in them.

TABLE 4

Percentage female and average Earnings, BY OCCUPATION: CANADA, 1991

\begin{tabular}{|c|c|c|c|c|}
\hline Occupation & $\begin{array}{c}\text { Average } \\
\text { Earnings } \\
\text { All Workers }\end{array}$ & Rank & $\begin{array}{c}\text { Employees: } \\
\text { Percentage Female }\end{array}$ & Rank \\
\hline Managerial & $\$ 40,264$ & 1 & 41.1 & 7 \\
\hline Science/Education & 37,565 & 2 & 46.4 & 4 \\
\hline Medicine/Health & 33,190 & 3 & 80.0 & 1 \\
\hline Forestry/Mining & 32,267 & 4 & 0.0 & 12 \\
\hline Fabrication/Construction & 27,786 & 5 & 10.7 & 11 \\
\hline Processing/Machining & 27,559 & 6 & 14.6 & 9 \\
\hline Transport/Material Handling & 24,849 & 7 & 14.6 & 9 \\
\hline Artistic/Recreation & 22,079 & 8 & 42.7 & 6 \\
\hline Sales & 21,793 & 9 & 46.2 & 5 \\
\hline Clerical & 19,496 & 10 & 79.9 & 2 \\
\hline Agriculture/Fishing & 16,833 & 11 & 23.0 & 8 \\
\hline Service & 15,151 & 12 & 56.7 & 3 \\
\hline
\end{tabular}

Source: Statistics Canada, Earnings of Men and Women (catalogue 13-217) 1991, Table 5.

Also, a number of studies have found that there is a negative correlation between the percentage of female employees in an occupation and the average earnings in that occupation. Using data from the 1986 Canadian census, for example, Baker et al. ${ }^{10}$ found that women's (full-time, full-year) earnings decreased by 1.03 percent for each

" Boulet \& Lavallee, supra note 7.

31" M. Baker et al., The Distribution of the Male/Female Earnings Differential: 1970-1990 ('Toronto: Department of Economics, University of Toronto, Working Paper No. 9307, August 1993). 
ten percent increase in the ratio of female-to-male employees in an occupation and that men's earnings decreased by 1.47 percent. "In other words, men's earnings were more adversely affected by working in a female-dominated occupation than were women's earnings.

There is some evidence to suggest, however, that the distribution of women among occupations is becoming more similar to the distribution of men. Gunderson, for example, concluded that

... in $1971,62 \%$ of females or males would have had to change occupations for the two genders to have an identical occupation distribution. By $1981,59 \%$ would have had to change, and by $1991,52 \%$ would have had to change....

The female work force's continued occupational segregation highlights the potential importance of policies designed to reduce that occupational segregation or its effects. ${ }^{12}$

Similar evidence has been found with respect to the distribution of men and women among disciplines at university. However, that evidence also appears to indicate that the narrowing of the educational distribution was due primarily to a movement by women into business schools and out of education during the 1970s and 1980s. Very little change was observed among other disciplines during that period, nor among any disciplines in the 1990s. ${ }^{13}$

Innate differences: There may be innate differences between the sexes with respect to such characteristics as IQ and physical aptitude. Research has provided evidence, for example, that women are smaller and weaker than men and has suggested that they have a lower threshold of pain. ${ }^{14}$ Women also do less well on tests of quantitative, mechanical, ${ }^{15}$ mathematical ${ }^{16}$ and visual-spatial ${ }^{17}$ ability than do men. On the other

G. Johnson \& G. Solon in "Estimates of the Direct Effects of Comparable Worth Policy" (1986) 76 American Economic Review 1117, found that the comparable reductions in earnings in the United States were 2.44 percent for females and 3.43 percent for males (per ten percent increase in the proportion of an occupation which was female).

Supra note 4 at 151 .

See S. Turner \& W. Bowen, "Choice of Major: the Changing (Unchanging) Gender Gap" (1991) 52 Industrial and Labor Relations Review 289.

P. Armstrong \& H. Armstrong, The Double Ghetto: Canadian Women and Their Segregated Work (Toronto: McClelland and Stewart, 1978).

P. England, "Socioeconomic Explanations of Job Segregation" in H. Remick, ed., Comparable Worth and Wage Discrimination: Technical Possibilities and Political Realities (Philadelphia: Temple University Press, 1984) 28.

M. Paglin \& A. Rufolo, "Heterogeneous Human Capital, Occupational Choice, and Male-Female Earnings Differences" (1990) 8 Journal of Labor Economics 123; and K. Wilson \& J. Boldizar, "Gender Segregation in Higher Education: Effects of Aspirations, Mathematics Achicvement, and Income" (1990) 63 Sociology of Education 62. Furthermore, although both Paglin and Rufolo and Wilson and Boldizar found that occupations which required mathematical skills were relatively well-paid, and although Wilson and Boldizar found that women had increasingly been entering those occupations which paid relatively well, Wilson and Boldizar also found that there was very little movement of women into occupations which required mathematical skills.

Armstrong \& Armstrong, supra note 14. 
hand, girls have been found to have greater verbal skills than boys and to be less aggressive. $^{18}$

Personal Preferences: Finally, it is possible some portion of the wage gap between men and women may be due to differences between them in their tastes for different types of jobs and in their attitudes toward work. That men and women differ in these respects is well established. For example, Hoffman and Reed ${ }^{19}$ found that a major source of the difference between the rates of promotion of male and female clerks in a large corporation was that the female clerks were much less likely than male clerks to apply for promotion or to express interest in promotion when they were asked whether they would like to be considered. ${ }^{20}$ As females tended to be the primary caregivers in their households, they felt unable to accept promotions as the work hours of the next highest jobs were much less flexible than the hours in their current jobs. Similarly, Filer ${ }^{21}$ has found that, compared to men, women reported that their jobs involved better relations with co-workers, required less commuting time, caused fewer illnesses, allowed greater flexibility with respect to time off and involved exposure to fewer hazards. ${ }^{22}$ Furthermore, other authors have found that women are less concerned with financial rewards than are men; ${ }^{23}$ that women prefer careers which involve helping others and working with people instead of those that provide high incomes or control over others; ${ }^{24}$ that women are more likely than men to avoid careers that require mathematical skills; ${ }^{25}$ that women are less likely than men to be risk-takers; ${ }^{26}$ and that young women's tastes concerning children and family life influence their choices of careers whereas these tastes have no effect on the career choices made by young men. ${ }^{27}$

18 Ibid.

1" C. Hoffman \& J. Reed, "When is Imbalance not Discrimination?" in W.E. Block \& M.A. Walker, eds., Discrimination. Affirmative Action, and Equal Opportunity (Vancouver: Fraser Institute, 1982) 187.

2. Hoffman \& Reed, ibid., also found that women are less willing to move to different locations to obtain promotions or new jobs than are men; and that they are more willing to quit their jobs in order to allow their spouses to accept transfers to new locations than are men.

$21 \quad K$. Filer, "Male-Female Wage Differences: The Importance of Compensating Differentials" (1985) 38 Industrial and Labor Relations Review 426.

22 In a subsequent study, Filer also reported that differences in personal preferences between men and women influenced their selection of occupations. See K. Filer, "The Role of Personality and Tastes in Determining Occupational Structure" (1986) 39 Industrial and Labor Relations Review 412.

23. R.C. Battallio, J.H. Kagel, \& M.O. Reynolds, "A Note on the Distribution of Earnings and Output Per Hour in an Experimental Economy" (1978) 88 Economic Journal 822.

24 T. Daymont \& P. Andrisani, "Job Preferences, College Major and the Gender Gap in Earnings" (1984) 19 Journal of Human Resources 408.

is Wilson \& Boldizar, supra note 16.

26 L. Subich et al., "The Effects of Sex-Role-Related Factors on Occupational Choice and Salary" in R. Michael, H. Hartmann \& B. O'Farrell, eds., Pay Equity: Empirical Enquiries (Washington: National Academy Press, 1989) 91.

27 A. Blakemore \& S. Low, "Sex Differences in Occupational Selection: The Case of College Majors" (1984) 66 Review of Economics and Statistics 157. 


\section{B. SYSTEMIC DISCRIMINATION}

In the preceding section it was implicitly assumed that differences between males and females with respect to productivity, employment costs and personal preferences were determined independently of any type of discriminatory practices. In other words, that model appeared to imply that discrimination existed only if individuals were not paid wages equal to the value of their labour or if wage differentials did not reflect differences in employment costs or personal preferences. However, it is clear that education, labour force participation and personal preferences may themselves be influenced by discrimination. These types of discrimination, in which the sources of the discriminatory practices are external to the labour market, are often called systemic discrimination.

For example, in the last decade, evidence has become available to suggest that the distribution of men and women among occupations has not arisen solely from differences between the sexes in tastes, abilities and education. In an early contribution, Brown et al. ${ }^{28}$ developed a statistical model to predict the occupational attainments of males based upon the observed values of such variables as education, number of children, experience and father's occupation. When they used the results of this model to predict the occupations chosen by women, they found that the "male model" predicted that the women would choose managerial and craft (e.g. plumber and carpenter) occupations far more often, and clerical and service occupations far less often, than they had been observed to. That is, women and men with the same characteristics were found to enter vastly different careers. Similarly, Bielby and Baron ${ }^{29}$ found that only 10 percent of the workers in a sample of nearly 61,000 were in mixed jobs (i.e. in job titles which had both men and women assigned to them).

Even differences in personal preferences may be the result of discrimination. Shepela and Viviano, ${ }^{30}$ in a survey of the psychological literature on sex differentiation, found that parents rated their new-born girls as smaller, finer-featured, softer and less attentive than did the parents of new-born boys, even though there were no significant differences in length, weight, or physical condition between the babies at birth; and that mothers played with a six month old baby in a different way when they were told that it was a boy than when they were told that it was a girl. Similarly, they cited numerous studies which found that storybooks ${ }^{31}$ and textbooks showed males in many more occupations than they did females; attributed passivity, docility, and dependence to girls

$2 \pi$

R.S. Brown, M. Moon \& B.S. Zoloth, "Occupational Attainment and Segregation by Sex" (1980) 33 Industrial and Labor Relations Review 506.

29 W.T. Bielby \& J.N. Baron, "Sex Segregation Within Occupations" (1986) 76 American Economic Review 43.

3) S. Shepela \& A. Viviano, "Some Psychological Factors Affecting Job Segregation and Wages" in H. Remick, ed., Comparable Worth and Wage Discrimination: Technical Possibilities and Political Realities (Philadelphia: Temple University Press, 1984) 47.

"Particularly insidious are children's story books in which the adventurous characters are almost always male, even when the protagonists are animals, such as rabbits or bears. A recent example is the animated movie, A Bug's Life, in which the hero was male even though it is well known that real worker ants are all female. 
six times more often than to boys; and attributed courage, exploration, imagination, industry, and problem-solving overwhelmingly to males.

\section{LABOUR MARKet Discrimination}

In The Economics of Employment and Earnings, ${ }^{32}$ I summarized the findings of eight Canadian studies which have attempted to determine how much of the 30 percent earnings differential between males and females (working full-time, full-year) can be "explained" using such objectively observable variables as age, education, years of experience, occupation and hours of work. These studies find that no more than half of this differential appears to result from differences in these characteristics between the sexes. Furthermore, when no accounting is made for differences in occupational choice between men and women, the remaining explanatory characteristics (education, experience, age, etc.) are able to explain less than one third of the wage differential. These findings suggest strongly that there is sex discrimination within the labour market. They also suggest that one of the sources of the "explained" differential is occupational choice - a difference that might also be the result of discrimination.

There is, however, some evidence to indicate that the findings of broadly based studies (such as those discussed above) overstate the amount of discrimination against women. First, Robb ${ }^{33}$ found that when the earnings of single women were compared to those of men, the portion of the wage gap which could be explained by differences in characteristics (between men and women) rose from 41.1 percent to 85.3 percent. In other words, for women as a whole, Robb was able to explain about 12 percent of the 30 percent gap. For single women, she was able to explain approximately 26 percent. Although this may indicate that employers discriminate against married women but not single women, a more plausible conclusion is that it indicates that many of the characteristics which employers consider to be important are not being measured. For example, these might include willingness to move, to accept promotions or to work overtime, number of days of sick leave, or desire to get ahead. Also, Filer ${ }^{34}$ found that, on average, men worked in jobs which were less desirable and more demanding than those in which women worked. When he made allowance for differences in the desirability of occupations, he found that the percentage of the male-female wage differential which he was able to explain rose from 48.3 percent to 65.5 percent.

Finally, many studies which examine detailed occupational categories find that the explained differential between male and female earnings rises to as much as $90-95$ percent, implying that it is occupational segmentation which creates the largest part of the male-female wage differential. One example of this type of study, by Wannell and

31 R. Robb, "Earnings Differentials Between Males and Females in Ontario, 1971" (1978) Canadian Journal of Economics 350.

34 Supra note 21 . 
Caron, ${ }^{35}$ reports the earnings of male and female university graduates in similar fields of study two and five years after graduation. In no field was the female to male earnings ratio less than 83 percent, and the unweighted average of ratios across all fields was $\mathbf{8 8 . 8}$ percent after two years and $\mathbf{9 0 . 5}$ percent after five years (See Table 5). Furthermore, most studies of individuals working in the same occupation, for the same employer, find that the "unexplained" earnings differential between male and female employees rarely exceeds 10 percent. Schrank, ${ }^{36}$ for example, found that Memorial University in St. John's, Newfoundland, had explicitly discriminated against married women faculty members as recently as $1959 .{ }^{37}$ Yet, by the 1973-1974 academic year, women's salaries had risen sufficiently relative to men's that he was able to explain 95.2 percent of the differences between male and female salaries on the basis of such characteristics as: highest degree obtained, numbers of publications, administrative duties, citizenship and university department. ${ }^{38}$ Similarly, Ferber and Green ${ }^{39}$ found that the unexplained differential at the University of Illinois (Urbana-Champaign) was less than 1 percent ( $\$ 98$ out of $\$ 15,101) ;{ }^{40}$ and Gerhart and Milkovich ${ }^{41}$ found a differential of 4 percent at a large, private (unnamed) firm. On the other hand, Cannings ${ }^{42}$ found that she was unable to explain 74.4 percent of the 13.9 percent difference between the wages of male and female middle managers in a large Canadian company.

Analytical Studies Branch, Statistics Canada, The Gender Earnings Gap Among Recent Postsecondary Graduates, 1984-92 (Research Paper Series) by T. Wannell \& N. Caron (Ottawa: Statistics Canada, 1994). W.E. Schrank, "Sex Discrimination in Faculty Salaries: A Case Study" (1977) 10 Canadian Journal of Economics 411 .

Schrank, ibid. at 413 , reports that the 1959 faculty contract contained the following clause: "Upon the marriage of a female teacher, her employment shall terminate, but the Board of Regents ... may continue her employment on a temporary basis...."

In a follow-up study conducted in 1985, Shrank found that the unexplained differential between male and female faculty at Memorial University was still less than 5 percent. (See W.E. Schrank, Sex Discrimination in Faculty Salaries at Memorial University: A Decade Later (Department of Economics, Memorial University, 1985) [unpublished].

M. Ferber \& C. Green, "Traditional or Reverse Discrimination? A Case Study of a Large Public University" (1982) 35 Industrial and Labor Relations Review 550.

It should be noted, however, that earlier studies of earnings at universities found much larger, unexplained male-female differentials. For example, David Katz in "Faculty Salaries, Promotions, and Productivity at a Large University" (1973) 63 American Economic Review 469, found a differential equal to 21.5 percent of women professors' salaries at a large, unnamed U.S. university; G. Johnson \& F. Stafford in "The Earnings and Promotion of Women Faculty" (1974) 64 American Economic Review 888, using a sample drawn from across the United States, found this differential to be between 4 and 11 percent for new hires, rising to between 13 and 23 percent for professors with 15 ycars experience. Large Private Firm" in R. Michael, H. Hartmann \& B. O'Farrell, eds., Pay Equity: Empirical Enquiries (Washington: National Academy Press, 1989) 23.

42 K. Cannings, "The Earnings of Female and Male Middle Managers: A Canadian Case Study" (1988) 23 Journal of Human Resources 34. 
TABLE 5

Female/Male Earnings Ratios by Field of Study, Canada: 1986 UNIVERSITY GRADUATES WORKING FULL-TIME, FULL-YEAR

\begin{tabular}{lll}
\hline Field of Study & \multicolumn{2}{c}{ Years } \\
& Two & Five \\
& 87.7 & 88.4 \\
Education & 94.7 & 97.4 \\
Fine Arts \& Humanities & 83.2 & 88.0 \\
Commerce, Economics, \& Law & 85.8 & 92.6 \\
Other Social Sciences & 86.1 & 84.3 \\
Agriculture \& Biology & 92.5 & 90.6 \\
Engineering & 91.5 & 91.9 \\
Math \& Physical Sciences & 88.8 & 90.5 \\
Average &
\end{tabular}

Source: Analytical Studies Branch, Statistics Canada, The Gender Earnings Gap Among Recent Postsecondary Graduates, $1984-92$ by T. Wannell \& N. Caron (Ottawa: Statistics Canada, 1994) at 12. [Note: I have excluded the fields identified as "None/Unknown" and "Medical and Other Health" due to heterogeneity.]

\section{SUMmaRY}

I believe that the following conclusions can reasonably be drawn from the studies reported above. First, even if women work in the "same" jobs as men and are paid the same wages, their lifetime earnings will be less than men's because women are less likely to "participate" in the labour force. As recent evidence suggests that the difference in participation rates is not likely to fall below 10 percent, the average woman's lifetime earnings are not expected to rise above 90 percent of the average man's. The latter percentage may be higher (or lower) for individual plaintiffs particularly for those with relatively high levels of education, or for those who had clearly-established career paths at the time of their injuries - but, for the average woman, that percentage is likely to apply unless there are dramatic changes in society's views about child care.

Second, women's earnings are also likely to lag behind men's due to differences in numbers of hours worked per week. At the moment, it appears that women will continue to be at least 20 percent more likely than men to work part-time and will, on average, work approximately 15 to 20 percent fewer hours per week. All else being equal, this implies a further 15 to 20 percent gap in average lifetime earnings. What is not clear, on the basis of current evidence, is whether this difference would continue if all sources of discrimination against women were to be removed. Again, it may simply result from differences in preferences concerning child care. 
Third, of the 30 percent earnings differential between males and females working full-time, full-year, approximately one-third (10 percentage points) appears to be due to observable differences in characteristics between the sexes - factors such as age, education, years of experience and hours worked. Another third appears to be due to differences in choice of occupation - women tend to enter occupations that have lower earnings than do those that are entered by men. The final third cannot be "explained" statistically. Most observers attribute this portion of the male/female earnings gap to discrimination in the workplace. Evidence suggests that changes in all three of these factors have contributed to the reduction in the male/female earnings gap observed in the last two decades. ${ }^{43}$

Fourth, there is also some evidence that as much as half of the portion that is "explained" by occupational choice also results from labour market discrimination. Hence, if all labour market discrimination was removed, the male/female earnings differential (among those working full-time, full-year) would fall from 30 percent to 15 percent. What is not clear is how much of the remaining 15 percent can be attributed to systemic discrimination and how much to innate differences between the sexes.

If it is assumed that the latter differential is due totally to innate differences, then even if labour market discrimination were to be abolished completely, women working full time would still make 15 percent less than men, on average. This means that if the statistical prediction approach was applied to a female plaintiff with no clear career path, the expectation would be that she would earn at least 15 percent less than a comparable male, (before allowance was made for labour force participation and parttime work). If, however, it was clear what occupation the plaintiff would have entered, the only difference between her full time earnings and those of a male in that same occupation would be the percentage due to labour market discrimination within that occupation. At the moment, this differential is approximately 5 to 10 percent. If it is anticipated that this type of discrimination will be eliminated in the next few decades, the statistical prediction approach would suggest that male earnings, in the relevant occupation, would be an appropriate measure of full time earnings for females.

\section{IMPLICATIONS}

The implications of the empirical findings in Section I will vary depending upon the age of the plaintiff at the date of the injury and the degree to which she had formulated her career plans. In this Section, I will consider three categories of plaintiffs: children, youths, and adults.

\section{A. Children}

In the category of "children," I include those plaintiffs who were young enough at the date of the accident that they had formed no specific career plans. Typically, information about the family background of the plaintiff - such as education and income of parents - is used to forecast the educational level that she would have 
achieved had she not been injured. ${ }^{44}$ For example, it might be argued that if the parents had both completed university, the daughter would have done so also. The question which then arises, in the current context, is whether it is the incomes of male graduates or female graduates that should be used to project the plaintiff's earnings. The answer to this question will differ depending on whether it is the "statistical prediction approach" or the "gendered earnings proposal" that is used.

Statistical prediction approach: The statistical prediction approach requires that the court predict whether the earnings of women, with the given level of education, will rise to equal the earnings of men with that education. The evidence cited in Section I indicates that the answer is mixed. On the one hand, it appears likely that both occupational segmentation and discrimination within the labour market will have declined appreciably by the time today's children enter the labour market. On this basis, the male/female earnings differential, for individuals working full-time within the same educational level, may well have fallen to a figure of less than 10 percent. $^{45}$

On the other hand, there is little evidence that the differences between males and females with respect to either labour force participation or hours worked per week will dissipate in the near future. It appears that, on average, women will continue to work approximately 10 percent fewer years than will men and approximately 10 to 15 percent fewer hours per week. These factors suggest that women's lifetime earnings will not rise above 75 to 80 percent of men's, even among women working full-time, full-year.

Gendered earnings proposal: The gendered earnings proposal suggests that the courts should not countenance any wage differential that arises from discriminatory behaviour. With respect to the two types of discrimination discussed in Section I - labour market and systemic — statistical evidence indicates that the former results in a lifetime earnings differential of approximately 15 percent. The gendered earnings proposal would clearly suggest that child plaintiffs be compensated for this portion of the total differential.

This still leaves a lifetime earnings differential of approximately 20 to 30 percent between males and females of similar educational levels. The statistical evidence concludes that this differential arises primarily because women choose different occupations from men, work fewer years than men, and work fewer hours per week. What the evidence has not been able to do, however, is to identify how much of these differences result from systemic discrimination and how much result from innate differences between males and females. school grades, where available.

4s It seems likely that women will continue to choose different occupations from men - even within educational categories - and that women in any age group will have less work experience than comparable men because they will have lower participation rates and will have worked fewer hours per week. 
It is well known, for example, that women are consistently overrepresented in the humanities and psychology and under-represented in engineering and economics. ${ }^{46}$ It is almost impossible, however, to determine whether this is because women are naturally more "nurturing" than men or whether it is because society has "programmed" them to "prefer" those disciplines. Similarly, there is virtually no objective evidence to determine whether some women "naturally" prefer to stay at home to look after their children or whether this apparent preference results from systemic discrimination against young girls.

Hence, a court wishing to apply the gendered earnings proposal will have no objective means for determining what that proposal implies. At one extreme, it could find that choices concerning occupation, hours of work or labour force participation are not influenced by systemic discrimination - and, therefore, conclude that girls' lifetime earnings will be approximately 20 to 30 percent less than boys'. At the other extreme, it would be open to the court to find that all of the observed differences between adult males and females had arisen from systemic discrimination - and, therefore, conclude that male earnings patterns should be used to represent the future earnings of young girls.

\section{B. YouTHS}

By "youths," I mean plaintiffs who were old enough when they were injured that they had developed relatively clear career plans, but had either not completed, or had only recently completed, their formal schooling.

Statistical prediction approach: Youths differ from children in three important ways. First, there is a shorter period between the injury and the time a youth will enter the labour market. Hence, it is less likely that women's starting salaries will have begun to catch up to men's by the time they enter the workforce.

Second, it will be much easier to determine the occupation that would have been chosen by a youth than by a child. Thus, as earnings differentials between men and women are much smaller within occupations than between them (see Section I), the projected earnings of females who are injured when they are youths will approximate the earnings of comparable males much more closely than will the projected earnings of females who are injured when they are children.

Third, the older the plaintiff is, the more reliable the information will be about that individual's degree of attachment to the labour force. For example, the court might reasonably conclude that a 22 year-old who had worked long hours to put herself through university would return to the labour force sooner following the birth of her children and work more hours per week, than would a similar individual who had "drifted" from job to job since dropping out of high school. The former would have projected earnings that were much more similar to those of males than would the latter. 
Gendered earnings proposal: Most of the arguments that I made concerning the application of the gendered earnings proposal to children apply mutatis mutandis to youths. I will not repeat them here.

It should be noted, however, that the gendered earnings proposal may require that the plaintiff be compensated as if she would have entered an occupation different from the one which she had planned to enter. That is, if it is concluded that systemic discrimination affects women's occupational choices, then the actual choices made by plaintiffs will not have reflected their true (non-discriminatory) earning capacities. As the goal of the gendered earnings proposal is to rectify the effects of discrimination, it requires that the court identify the occupations that plaintiffs would have entered had there been no systemic or labour market discrimination - not the occupations that the plaintiffs actually entered (or planned to enter).

As systemic discrimination begins from the moment of birth, any attempt to determine what the plaintiff would have done had she not been subjected to such discrimination cannot employ any observations of the plaintiff's actual behaviour. Her choices of career and educational level, even her aptitude at mathematics and languages and her preferences concerning the bearing and raising of children, may have all been influenced by discrimination. The result is that the gendered earnings proposal will require that the same factors be used to forecast the earnings of youths as are used to forecast the earnings of children (e.g. parents' and brothers' education and earnings).

\section{Adults}

By "adult," I mean an individual who had already embarked on a clearly-identified career at the time of her injury.

Statistical prediction approach: Adults will have revealed their occupational choices, their hours of work and their attachments to the labour force. Hence, the statistical prediction approach asks only whether any earnings gap between females and comparable males, within the plaintiff's chosen occupation, are likely to be reduced within the plaintiff's remaining working lifetime. The answer to this question will depend, first, on the plaintiff's age and, second, on information specific to her occupation. Age is important both because rates of promotion tend to be much lower for older individuals (and, hence, there are fewer opportunities for women to "catch up" to men) and because older women will have fewer years in which to reduce the earnings gap (before retirement). Little can be said here about occupation-specific factors as these vary considerably from one occupation to another.

Gendered earnings proposal: Application of the gendered earnings proposal to older plaintiffs will encounter two difficulties. The first of these is informational. As with youths, the plaintiff's actual lifetime experiences will be of little value when determining what their "non-discriminatory" earnings potentials would have been. The court will have to make a determination of what their earnings would have been had 
they been treated like males from birth. This, perhaps, is the reason why Elaine Gibson, ${ }^{47}$ in her ground-breaking article on the gendered earnings proposal, suggested that damages might be based on "need" instead of on some calculation of what the plaintiff's earnings might have been.

The second difficulty is a practical one. By the time they reach their late $40 \mathrm{~s}$, women are often earning 50 percent less than comparable males - or, if they have chosen to remain out of the labour force, even 100 percent less. One can imagine that the courts would find it difficult to justify compensating an injured woman for a "loss" of $\$ 50,000$ per annum when the woman who replaced her at her place of employment was earning only $\$ 25,000$.

\section{CaSe Law}

1 am aware of 14 Canadian cases that have discussed the use of male earning patterns to project the earnings of females. In this section, I review these cases in order to determine whether they apply either the statistical prediction approach or the gendered earnings proposal. For ease of comparison with the discussion in Section II, I divide the cases according to the ages of the plaintiffs. Seven of the cases, all of which were decided before 1996, dealt with children. The remaining seven, five of which were decided after 1996, dealt with youths. None dealt with adults, an observation concerning which I will comment below.

\section{A. CHILdREN}

It appears that the earliest case to deal explicitly with the argument that male earnings data might be used to predict the earnings of young females was Prather v. Hamel. $^{48}$ Clement J.A. (dissenting in part), speaking only of the time between graduating from school and beginning a family, commented that:

\footnotetext{
within this more limited period, in the absence of evidence, I would not feel justified in differentiating greatly between the future earning capacity of a boy and girl. In today's society women are progressing towards an equality of status with men not only in respect of rates of pay, but also in the range of job opportunities. ${ }^{9}$
}

Although Justice Clement's ruling signalled a willingness to accept the statistical prediction approach, its restriction to a few years at the beginning of the plaintiff's career appears to have discouraged any further claims based on this approach. It was not until 1990, in British Columbia, that the argument resurfaced in court. Of the six cases dealing with children decided since that time, four accepted the statistical prediction approach, none accepted the gendered earnings proposal, and two rejected both, basing projected earnings on female earnings patterns instead. 
Female earnings patterns: The first decision in this decade to consider the argument that male earnings data should act as the basis for projecting female earnings was Cherry (Guardian ad litem) v. Borsman..$^{50}$ Without providing any discussion of the issue, the trial judge employed female earnings data to forecast the loss of earnings of an infant plaintiff who had suffered permanent brain damage. The British Columbia Court of Appeal then rejected the plaintiff's argument that male earnings data should be substituted for female, primarily on the basis that the appellate court should not interfere with a trial court's findings of fact.

The second case to rely solely on female earnings data was $D . v . F .{ }^{51}$ an incest case. The decision did not clearly dismiss the statistical prediction approach as it was found that the plaintiff's loss would continue for only three years after the trial, a period short enough that female earnings could not be expected to change relative to male. Justice Humphries did, however, appear to reject the gendered earnings proposal, arguing that "... I should not take into account possible changes in social policy, especially when the time period, as here, is so short." 52

Statistical prediction approach: The next case to consider the issue, Toneguzzo-Norvell (Guardian ad litem) v. Burnaby Hospital, ${ }^{53}$ bridged the theoretical gap between Cherry and the cases that followed. At trial, the plaintiff discussed the argument that male earnings should be used to project female earnings, but failed to enter any data concerning males. Consequently, the trial judge, although apparently willing to accept the statistical prediction approach, did not feel that he had sufficient information before him to calculate the implied loss. The plaintiff appealed this portion of the decision to both the Court of Appeal and the Supreme Court of Canada but was unsuccessful. Both courts implied, however, that they were sympathetic to the argument and indicated that their failure to rule in the plaintiff's favour occurred, in large part, because they lacked sufficient information about male earnings.

A further step towards the use of male earnings was taken in Tucker v. Asleson (Guardian Ad Litem). ${ }^{54}$ For the first time, a court explicitly employed male earnings as the basis for calculating a female plaintiff's loss. Finch J. accepted the argument that a woman's earning capacity could be measured by the income of a comparably-educated male. What he called her earning potential, however, would be less than her capacity as the result of various contingencies of life. Although he made no explicit statement to this effect, it appears that the most important of such contingencies envisioned by Justice Finch were those which might prevent a woman from achieving earning parity with a comparable man - lower labour force participation, shorter working hours, selection from among a different set of occupations, etc. Accordingly, he discounted the

s)

s)

52

53

54

(1992) 94 D.L.R. (4th) 487 (B.C.C.A.), aff'g (sub. nom. Cherry (Guardian) v. Borsman) (1990), 75 D.L.R. (4th) 668 (B.C.S.C.) [hereinafter Cherry].

[1995] B.C.J. No. 1478 (B.C.S.C.).

Jbid., para. 24.

[1994] I S.C.R. 114, 110 D.L.R. (4th) 289, affg (1992), 73 B.C.L.R. (2d) I16 (C.A.) [hereinafter Toneguzzo].

(1991) 86 D.L.R. (4th) 73 (sub nom. Tucker (Public Truslee of) v. Asleson) 62 B.C.L.R. (2d) 78

(B.C.S.C.) [hereinafter Tucker]. 
plaintiff's earning capacity - the lifetime value of male earnings, of $\$ 947,000-$ by 63 percent, to produce an estimate of her lifetime potential of $\$ 350,000 .{ }^{55}$

The next case in this line, Mulholland (Guardian ad litem) v. Riley Estate ${ }^{56}$ took the argument one step further. The trial judge, Melvin J., explicitly accepted what I have called the statistical prediction approach, arguing that:

...the profile of earnings for young woman entering the marketplace at about 1991 would lie somewhere between the existing statistical information for females and males in British Columbia. ${ }^{57}$

He then based the plaintiff's damages on the mid-point between male and female earnings data. The Court of Appeal subsequently refused to overturn this decision.

Finally, in $A$.(D.A.) v. B. (D.K.) $)^{58}$ Wilson J. went some way towards acceptance of the gendered earnings proposal, concluding:

Counsel states that it would be discriminatory to use female comparative earnings, as to do so would perpetuate discrimination that exists in the workplace. She relies upon a decision from British Columbia, where male projected eamings were used, with reduction for contingencies to predict future income loss for a female.

There is merit to this recent development in the caselaw. The objective of calculating income loss is to fairly compensate for loss, using the most accurate assumptions. To predict future income loss based on past inequities that are being addressed may be both discriminatory and inaccurate. ${ }^{59}$

In spite of this wording, Wilson J. ruled that:

Had I been applying a comparative analysis for earnings, I would have utilized the blended male and female statistics as suggested by counsel, as reasonable for predicting the future income loss."

Although the wording of the rationale was consistent with the gendered earnings approach, the calculation of damages appears to have been based on a projection that female earnings would soon begin to catch up to male earnings - a calculation which has its foundation in the statistical prediction approach.

\section{B. YouTHS}

Of the seven cases that dealt with youths, six adopted the statistical prediction approach and one the gendered earnings proposal. None of the cases refused to consider male earnings data when determining lifetime earnings for female plaintiffs.

Note: The latter was only $\$ 48,000$ more than the average lifetime value of female earnings. (1995) 12 B.C.L.R. (3d) 248 (B.C.C.A.) [hereinafter Mulholland].

Ibid., para. 34.

(1995) 27 C.C.L.T. (2d) 256 (Ont. Ct. (Gen. Div.)).

lbid. at 273, paras. 68-69.

Ibid. at 273, para. 71 . Note: the court had found that the plaintiff had not suffered a loss. Hence, the decision with respect to damages was explicitly obiter. 
Statistical prediction approach: In three cases - S.M.A.B. v. J.N.H., ${ }^{61}$ Morris v. Rose Estate, $^{62}$ and Shaw (Guardian ad litem) v. Arnold $^{63}$ - the court accepted the proposition that the disparity between male and female earnings will narrow in the future. In each, the court concluded that this narrowing would not occur quickly enough to remove the disparity within the plaintiff's lifetime. Accordingly, damages were based on an average of male and female earnings data.

In both B.I.Z. v. Sams, ${ }^{64}$ and Mozersky v. Cushman, ${ }^{65}$ the court concluded that there was sufficient information about the plaintiff that it could identify with some confidence the specific occupation into which she would have entered. Further, in both occupations, earnings of females were found to be similar to those of males. Nevertheless, the plaintiffs' lifetime earnings were not set equal to those of males. They were reduced to take into account females' relatively low rates of labour force participation and high rates of part-time work.

Finally, in Terracciano (Guardian ad litem) v. Etheridge, ${ }^{66}$ Justice Saunders argued strongly that statistics of average female earnings should not be used to predict the future earnings of the plaintiff:

Apart from the fact that these statistics perpetuate historical inequality between men and women in average earning ability, and that they have hidden in them serious discounts for lower and sporadic participation ... which are duplicated by many of the negative contingencies used by economists to massage the numbers downward, such statistics may provide little assistance in predicting the future of a particular female plaintiff....

Indeed, it may be as inappropriately discriminatory to discount an award solely on statistics framed on gender as it would be to discount an award on considerations of race or ethnic origin. I am doubtful of the propriety, today, of this Court basing an award of damages on a class characteristic such as gender, instead of individual characteristics or considerations related to behaviour...."7

It is possible to find support for both the statistical prediction approach and the gendered earnings proposal in this quote. The latter is supported by Justice Saunders' argument that it would be discriminatory to discount an award because of statistics framed on gender. On the other hand, the former is supported by her argument that the award should be based on individual characteristics and behaviour. It appears, however, that the assessment of damages was motivated more by the latter than the former, as the award was found by reducing male lifetime earnings by more than 15 percent. ${ }^{68}$

[1991] B.C.J. No. 3940 (B.C.S.C.) (QL).

[1993] B.C.J. No. 2679 (B.C.S.C.) (QL).

[1998] B.C.J. No. 2834 (B.C.S.C.) (QL).

[1997] B.C.J. No. 793 (B.C.S.C.) (QL).

[1997] O.J. No. 4912; (1997) 48 O.T.C. 161 (Ont. Ct. (Gen. Div.)).

[1997] 7 W.W.R. 185, (1997) 33 B.C.L.R. (3d) 328 (B.C.S.C.) [hereinafter Terracciano].

Ibid. at 206, paras. 80 and 81 .

The plaintifl's claim for $\$ 1,000,000$ was six percent less than the male carnings figure before adding an allowance for fringe benefits. Justice Saunders awarded $\$ 950,000$ inclusive of fringe benefits (which would usually amount to at least an additional 5 percent). 
Nevertheless, Terracciano definitely set the stage for MacCabe, the first case to make explicit use of the gendered earnings proposal.

Gendered earnings proposal: In MacCabe, ${ }^{69}$ Johnstone J. made it clear that she would not countenance awards grounded in discrimination:

It is entirely inappropriate that any assessment I make continues to reflect historic wage inequities. I cannot agree more with Chief Justice McEachern of the British Columbia Court of Appeal in Tucker, supra, that the courts must ensure as much as possible that the appropriate weight be given to societal trends in the labour market in order that the future loss of income properly reflects future circumstances. Where we differ is that I will not sanction the "reality" of pay inequity.... The courts have endeavoured to alleviate this discrimination with the use of male or female wage tables modified by either negative or positive contingencies. However, I am of the view that these approaches merely mask the problem....

A growing understanding of the extent of discriminatory wage practices and the extent of this socictal inequity must lead the Court to retire an antiquated or limited judicial yardstick and embrace a more realistic, expansive measurement legally grounded in equality. Equality is now a fundamental constitutional value in Canadian society."

She ruled that the plaintiff was to be compensated according to the male earnings scale in the occupation she was predicted to have entered, physiotherapist. Furthermore, where contingencies (such as labour force participation, part-time work, and unemployment) were gender specific, the contingencies applicable to males (except for life expectancy) were to be used.

Arguably, the MacCabe decision was the first to apply the gendered earnings proposal. Not only did Justice Johnstone employ the philosophical arguments associated with that proposal (as had Saunders J. in Terracciano), but, by ruling that male contingencies were to be used, she crafted a damage assessment that relied on those arguments.

This is not to say that a similar level of damages would not have resulted from an application of the statistical prediction approach. In spite of having become a quadriplegic while in high school, Ms. MacCabe had, by the date of the trial, completed a university degree and entered graduate school. This implies that she was a highly motivated individual - one who might have been expected to have completed more education and worked more hours than the average female. Indeed, Justice Johnstone's conclusion that Ms. MacCabe would not have entered graduate school (had the accident not occurred) seems very conservative. It, perhaps, balances her assumption that Ms. MacCabe's hours of work would have reflected those typical of a male.

Finally, it is worth noting that, in the passages quoted above, Justice Johnstone referred to "societal trends in the labour market" and to "discriminatory wage 
practices." 71 That is, her decision appeared to be directed to labour market discrimination and not to systemic discrimination. This interpretation is confirmed by the observation that she did not attempt to determine what occupation Ms. MacCabe would have entered had she been a male. Instead, she accepted as given the occupation which Ms. MacCabe had chosen, given her upbringing as a female. Although it is unlikely that this distinction would have had a significant effect on the determination of Ms. MacCabe's award, it could well have done so had Ms. MacCabe chosen a more "traditional" female career path.

\section{ADULTS}

To my knowledge, no decision involving an adult plaintiff - that is, one whose career path was well established at the time of the accident - has considered whether male data should be used to predict female earnings patterns. This observation is consistent with the view that the courts are applying the statistical prediction approach. The reason for this is that once an individual has established a career, the predicted path which that individual will take in the future is largely independent of the individual's sex. For example, the career paths of 25 year-old law school graduates who have not yet chosen fields of specialization or sizes of law firms may differ quite significantly between males and females. Thus, a court which wished to apply the statistical prediction approach would have to treat the genders differently. The comparable differences between male and female 45 year-old family lawyers, working in three-person law firms, however, may be sufficiently small that application of the statistical prediction approach would not require that gender be considered explicitly.

If the court wished to apply the gendered earnings proposal, however, it would not consider what the plaintiff's prospects would have been had she continued in her career. Rather, it would calculate what her prospects would have been had she continued in the career she would have entered had she been a male. The court would be required to ask, for example, whether the female family lawyer referred to above would have chosen a different specialization had there been no discrimination against women. It would also be required to ask whether a 45 year-old homemaker would have remained in the labour market had she been a male. That the courts have not chosen to engage in such an exercise may suggest that they find it too speculative. If so, application of the gendered earnings proposal may be restricted to children and youths.

\section{Summary}

Like most changes in the common law, the court's attitude towards the use of male earnings data as the basis for predicting female earnings has undergone a gradual evolution. The earliest cases all dealt with plaintiffs who were young enough that it was relatively uncontroversial to predict that the male/female earnings gap would be reduced significantly by the time the plaintiffs entered the workforce. These cases evolved from Cherry and Tonneguzzo, in which the court merely signalled a willingness to consider the statistical prediction approach, through those like Tucker, in which female earnings 
were discounted heavily relative to male, and finally to Mulholland, which concluded that half of the male/female gap would be closed.

Only when a sufficient set of precedents had been established with respect to children did a line of decisions involving young adults develop. Some of these particularly B.I.Z., Mozersky, and Shaw - adopted reasoning similar to that in Mulholland. In Terracciano, however, the court indicated that it was willing to accept the proposition that it would be discriminatory to base an award on women's historical earnings patterns. This "willingness" was then put into effect in MacCabe.

What is not clear is whether MacCabe was merely a step in an evolutionary process towards a new consensus, whether it represents the end of such a process, or whether it will become an evolutionary "backwater" with few subsequent adherents. My predictions are:

1. The courts will find the calculations necessary to rectify discrimination against adults to be too speculative. At the most, they will take into account the possibility that women's earnings will rise more quickly than men's over the next few decades. They will not attempt to determine the occupation that female plaintiffs would have entered had they been male; nor will they assume that women with a history of part-time employment would have worked fulltime in the future had they not been injured.

2. Once the court has determined the occupation a young plaintiff would have entered, had she not been injured, they will assume that her earnings pattern would have approximated that of a male. An exception may be made, however, if it is clear that a particular plaintiff would have followed a "traditional" female pattern - for example, if it is clear that she would have remained out of the labour force for more than a year following the birth of each of her children. The court will not, however, enquire what occupation the plaintiff would have entered had she been a male.

3. The courts will begin to use male earnings data, by education level, to predict the future earnings of female children - possibly discounted by a small contingency to allow for the lower labour force participation rates of women.

To clarify, these are predictions, based on a reading of the case law which has developed over the last decade. I have tried, in this article, to avoid introducing my own normative judgements concerning what the law "should be." Also, it should be noted that, as the law in this area is still evolving, these predictions represent "educated guesses." It will require at least another decade before a clear pattern can be discerned.

\section{Conclusion}

The Canadian courts are using two approaches to the prediction of the future earnings of female plaintiffs. In one, which I called the statistical prediction approach, they employ the best available statistics to forecast what the plaintiff's earnings would 
have been had she not been injured. As the male/female earnings gap has been closing in recent years, this approach often suggests that the plaintiff's earnings will resemble the historical earnings pattern of a male more closely than that of a female. In the second approach, which has been called the gendered earnings proposal, the courts have accepted the argument that most of the earnings gap between men and women has been due to discrimination. To avoid entrenching this discrimination, the courts use male earnings data when forecasting the earnings of female plaintiffs.

In Section I of this comment, I concluded that the statistical evidence shows that women's earnings are likely to continue rising relative to men's - particularly among women who chose to work full-time for their entire careers. Nevertheless, I also concluded that statistical sources provide little evidence of a closing in the gap with respect to either labour force participation rates or hours worked per week. Thus, although individual women, with particularly strong attachments to the workforce, might experience career paths similar to those of men, the average woman will continue to have lower lifetime earnings than will the average man.

In Section III of this comment, I concluded that the courts appear to be moving towards a system that mixes the statistical and gendered earnings approaches together. On the one hand, the courts appear to have accepted the statistical evidence that women will continue to choose careers that differ from men's. In consequence, they do not ask what occupation a female plaintiff would have chosen had she been a male. Instead, the courts compensate her according to the occupation she had planned to enter, even though her choice may have been affected by discriminatory factors. On the other hand, the courts appear to be willing to ignore the evidence that women will continue to be more likely than men to work part-time or to take significant amounts of time out of the labour market. Thus, in cases like B. I. Z., Mozersky, and MacCabe, they apply only very limited discounts for those contingencies.

From a philosophical perspective, this hybridization of the law is difficult to defend. From a practical perspective, however, it might be justified as a reasonable compromise between two conflicting doctrines. 